Revista de Filología Románica

ISSN: 0212-999X

http://dx.doi.org/10.5209/RFRM.58175

\title{
Homenaje de Irene Zamora Soto a su abuelo
}

Recibido: 17 de abril de 2016 / Aceptado: 4 de octubre de 2017

Buenas tardes a todos, gracias, gracias, gracias, es todo lo que puedo decir a los organizadores de este homenaje, así como a los asistentes. Muchas gracias por vuestro esfuerzo y vuestra ilusión, y por hacer que este homenaje haya sido posible.

Me consta que ha supuesto un trabajo enorme coordinar a tanta gente y recopilar tanta información y muchas veces ni nos damos cuenta de que esos grandes esfuerzos nos hacen disfrutar de esas pequeñas cosas que mucha gente, incluido mi abuelo, cree que quedan en el olvido.

Escribía de su puño y letra ¡Y vaya letra! Que ni el mismo entendía a veces y se reía, y entonces yo me enfadaba. Yo le ayudaba a pasarlo a ordenador, pero él prefería la máquina de escribir. Ponía una hoja de calco y me decía: ¿Ves? Así hago varias copias de una vez. "Sí, abuelo, mira, yo pulso aquí y me salen tooodas las copias que tú quieras". "Ya, bueno, para eso hago xerocopias". "¿Xerocopias? Serán fotocopias, abuelo". Y a eso ya solo podía contestar, entre dientes, "Hay que joderse, con la chotita."

Eso de que "Qué maravilla esto de las tecnologías", no estaba en su vocabulario. Y, sin embargo, hoy me permiten participar en este acto y acercarme un poco más a él. Me habría encantado estar en persona, así que me toca, agradecer también, a las tecnologías, a mi madre, a Carmen y a Lidia por planear este vídeo conmigo. Gracias a las tecnologías he podido disfrutar de esas pequeñas cosas que, en realidad, son las grandes. He podido oír su voz una vez más, he disfrutado escuchándole decir que su chepa se debe a sus alas de ángel. Y eso es lo que es, un ángel, que me hace sonreír cada día cuando tecleo en mi ordenador y recuerdo el eterno sonido de su máquina de escribir; cuando me asusto por una corriente de aire que provoca un portazo y recuerdo sus sobresaltos por el mismo motivo; cuando como chocolate y recuerdo cómo jugaba con el envoltorio de los bombones cuando se los comía, o cuando me bebo un zumo de naranja y recuerdo ese olor impregnado en sus manos, a base de pelar naranjas a todas horas. Y caprichos del destino, aquí me encuentro, enseñando español a los americanos y lidiando con editores. ¿Cómo no me voy a acordar?

De esas pequeñas cosas podría seguir hablando eternamente y se mezclarían con las grandes porque una no sabe ya cuál es cuál. Sus consejos, sus canciones, su sordera selectiva, sus viajes, sus historias de Madrid. Todo lo recuerdo, no importa el tiempo que pase.

Porque [él] estaba equivocado cuando decía que pasaría el tiempo y nadie le recordaría. Le recordamos. Alumnos, lectores, amigos, familiares, compañeros, colegas y conocidos. Por las grandes cosas y por las pequeñas. 
Así que, sirva este homenaje para llevarle la contraria, que ya me parece estar oyendo a un ángel decir "Hay que joderse, con estos chotitos".

Empecé diciendo gracias y termino diciendo: gracias a todos y especialmente a ti, abuelo. 